\title{
Artificial Diet of Silkworms (Bombyx Mori) Improved With Bee Pollen - Biotechnological Approach in Global Centre of Excellence For Advanced Research in Sericulture and Promotion of Silk Production
}

\author{
Adela Ramona MOISE ${ }^{1}$, Lucia Lelia POP ${ }^{1}$, Thomas Vicentiu VEZETEU ${ }^{1}$, Bianca DOMUȚ \\ AGOSTON $^{1,}$ Claudia PAȘCA ${ }^{1}$ and Daniel Severus DEZMIREAN ${ }^{1 *}$ \\ 1 Faculty of Animal Science and Biotechnologies, University of Agricultural Sciences and Veterinary \\ Medicine Cluj-Napoca, 3-5 Calea Mănăştur Street, 400732 Cluj Napoca, Romania \\ *corresponding author: ddezmirean@usamvcluj.ro
}

Bulletin UASVM Animal Science and Biotechnologies 77(1)/ 2020

Print ISSN 1843-5262; Electronic ISSN 1843-536X

DOI:10.15835/buasvmcn-asb: 0004.20

\begin{abstract}
Global Centre of Excellence for Advanced Research in Sericulture and Promotion of Silk Production (GCEARS-PSP) is an important organisation for Romanian sericulture; the main aim of the centre is the revival of Romanian sericulture, the maintenance of Bombyx mori gene pool and the development of research in this domain. The moderate continental climate in Romania does not permit the rearing of silkworms all over the year and consequently, the production of silk is related to mulberry leaves production. A dietary substituent for the mulberry leaves is therefore needed. We herein tried to develop an alternative food recipe by including different concentrations of bee pollen to the commercial artificial diet recipe and measure its impact on larvae length and weight and silk production; our results demonstrate a good adaptability of silkworms to the artificial diet, and the addition of bee pollen improves the studied parameters, but without significant differences.
\end{abstract}

Keywords: artificial diet, biotechnologies, GCEARS-PSP, silkworms

\section{Introduction}

Sericulture depends on rearing of silkworms (Bombyx mori L.) on mulberry leaves, which is its traditional food; there are more than 1000 varieties of silkworms worldwide (monovoltine, bivoltine and multivoltine), and in Romania the gene pool is formed by 50 breeds and hybrids (monovoltine). For this consideration the existence of mulberry plantations is binding. Silk and eggs production are directly correlated with larval growth and mulberry trees development (Bhattacharyya et al., 2016). The quantity and quality of mulberry leaves (Vlaic et al., 2006a; Vlaic et al., 2006b) depends on different climatic factors and field practices, anyhow the climatic conditions in Romania does not permit to rear the silkworms all over the year.

Worldwide many sericulture research works were developed, in order to found suitable receipes for silkworm's nutrition. More of them are based on dried mulberry leaves with different supplement nutrients ( Das et Medda, 1988; ElSayed and Nagda, 1999; Islam et al., 2004).

In traditional food system, the mulberry leaves must be fresh enough to meet the nutritive demands and preferences of silkworms (Kanafi et al., 2007; Vlaic et al., 2008); this system face some 
others disadvantages, as high cost of mulberry fields plantations, the space request (rearing rooms), leaves transportation and intensive labour. The rearing system based on artificial diet, especially in country with developed sericulture, like Japan or Indiashould solve some of these farmers issues. ; Those may purchase the artificial diet instead of cultivating the mulberry trees, especially if they use polyphagous silkworm races (Shinbo and Yanagaw, 1994); the artificial diet is a valuable solution for farmers when the mulberry leaves are missing (for unfavourable weather condition) or for the winter rearings In the same time, it represent a good option for researchers, due to the fact that the biological material can be obtained during throughout the year.

Due to these considerations, Global Centre of Excellence for Advanced Research in Sericulture and Promotion of Silk Production (GCEARS-PSP) , functioning in the University of Agricultural Sciences and Veterinary Medicine Cluj-Napoca Romania, has an important scientific activity and for these reason it has to produce silkworms larvae for the laboratory activities even in the winter.

One of the first silkworms feeding with artificial diet was reported in Japan in 1977. Since then, many researchers in sericulture domain worked on artificial diet (Liaw, 1990;Shinbo and Yanagaw., 1994; Cappellozza et al., 2005), improving different recipes and making interesting studies on silkworm nutrition (Yanagawa et al., 1991; Babu et al., 1992; Chamudeswari et al., 1994; El-Hattab, Samia,M., 2002; Etebari et al., 2002). For example, Cappellozza et al. (2005) reported interesting results using an artificial diet formed by different proportions of dried mulberry leaf powder, defatted soybean meal, wheat meal, corn starch, soybean fiber, citric acid, ascorbic acid, salt mixture, agar, vitamin mixture, sorbic acid, propionic acid, chloramphenicol and $\beta$-sitosterol. Generally, dry components of artificial diet are mixed with antibiotics like chloramphenicol or dihydrostreptomicine, propionic acid and ascorbic acid, substances that, according to Bhattacharyya et al. (2016) protect the silkworms against microbiological contamination and support the whole developmental stages of silkworms. Anyhow, already in 1971 and then in 1983, Horie and Watanabe demonstrated that soybean meal added as protein source in silkworm diet increase the larvae silkworm's weight and silk glands.
This study was conducted at University of Agricultural Sciences and Veterinary Medicine Cluj Napoca in GCEARS-PSP, which is an important organisation for Romanian sericulture; the main aim of the centre is the revival of Romanian sericulture, the maintenance of Bombyx mori gene pool and the development of research themes in this domain.

The aim of the study was to demonstrate the functionality of artificial diet on silkworms and to test the effect of bee pollen added in different concentrations in their daily diet. The novelty of this study consists in testing the artificial diet for the first time in Romania, not only for Romanian silkworm's breeds, but on the abroad ones, too. The study of the bee pollen effect on biological parameters of larvae and cocoons is the other originality element of the study.

\section{Materials and methods \\ Materials}

The biological material used in this study was the C122, JH3, A033 and B1 silkworm (Bombyx mori L.) breeds and comes from the genetic pool available in Global Centre of Excellence for Advanced Research in Sericulture and Promotion of Silk Production from UASVM CN; the tested breeds has Uzbekistanian (C122), Japanese (JH3), and Romanian origins (A033- Alb Orşova line 33 and B1 - Băneasa line 1). The dried artificial diet was purchased from Agricultural Academy Scientific Centre on Sericulture - Vratsa, Bulgaria. The bee pollen added in silkworm's recipes comes from the apiary of Apiculture Department of Faculty of Animal Science and Biotechnologies from UASVM CN.

\section{Methods}

The incubation of silkworm's eggs was done under controlled parameters, in an incubator at $24^{\circ} \mathrm{C}$, and the hatching was registered after 12 days. In the first and second larvae instars the temperature in the incubator was fixed at $29^{\circ} \mathrm{C}$, in the third instar at $27^{\circ} \mathrm{C}$, in the forth at $26^{\circ} \mathrm{C}$ and in the last instar at $24^{\circ} \mathrm{C}$. During the spinning period of cocoons the temperature was maintained at $24^{\circ} \mathrm{C}$. After hatching the larvae were kept in plastic boxes (Figure $1 \mathrm{~A}$ and $1 \mathrm{~B}$ ), in the forenamed condition, with the lid tight fitting during the first three stages and then the boxes lids were removed.

The powder moisturizing was done with distillate water in proportion of $1: 2.4$, and the 


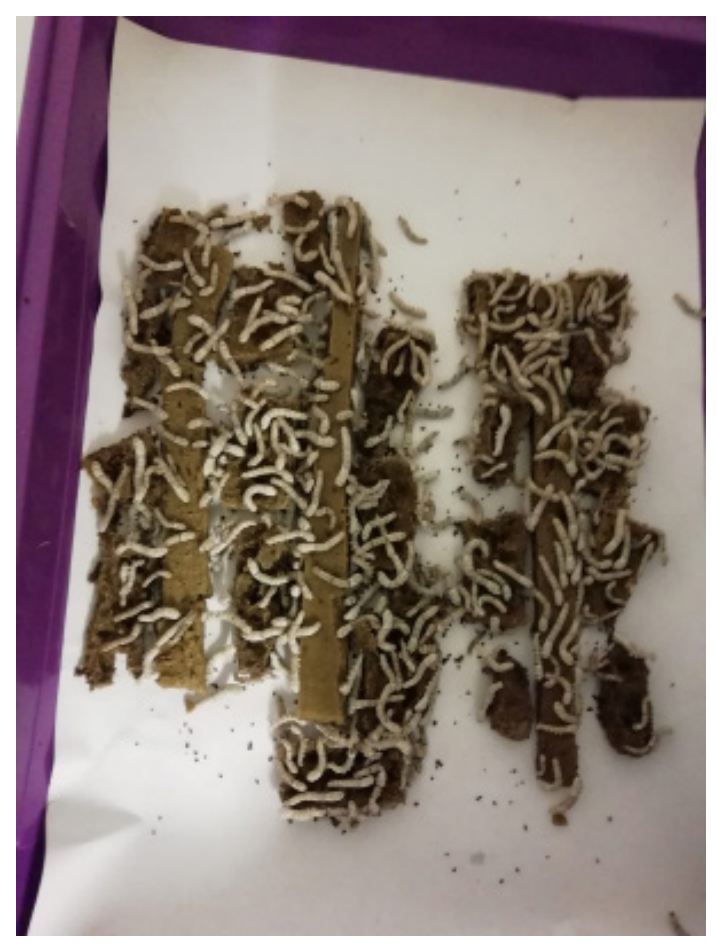

Larvae in the third instar

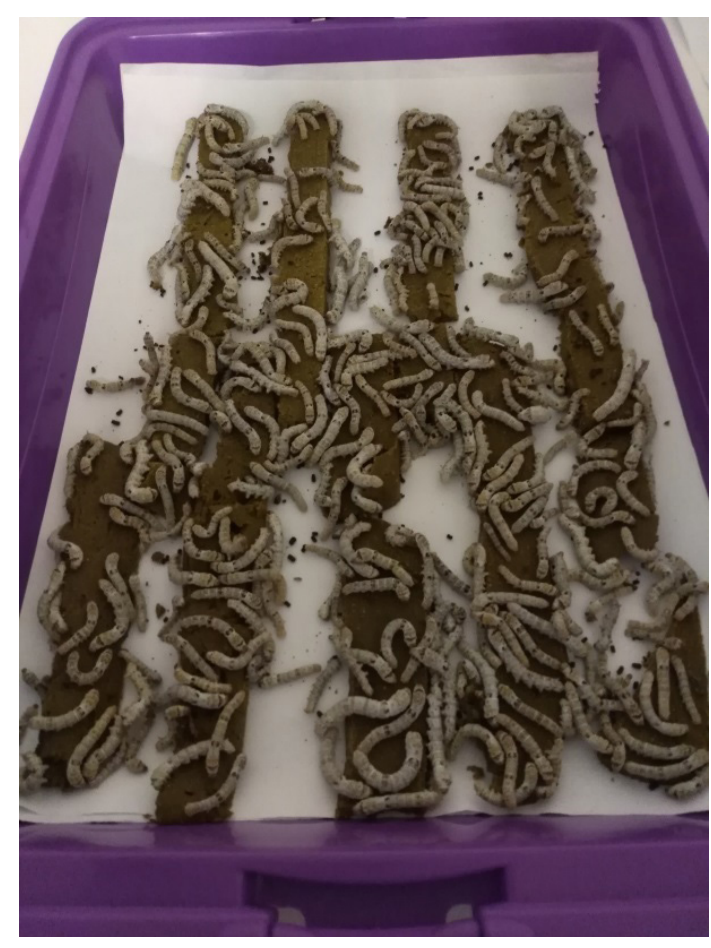

Larvae at the end of the fourth instar

Figure 1. Romanian silkworm breed (B1) fed with artificial diet

obtained chow was microwave and stored before serving according to producer's indications. The food was administrated ad libitum and the boxes were cleaned daily by levigation with formaldehyde (1\%) and the paper under silkworms being changed every day. The artificial diet was prepared from 250 grams of dried powder mixed with 600 $\mathrm{ml}$ of water, microwave for 5 minutes and kept in refrigerator at $4^{\circ} \mathrm{C}(\mathrm{V} 1$ variant- considered as control group).

For V2 and V3 recipe dried bee pollen was added for reaching the $1 \%$ and $5 \%$ concentration (dryweight), respectively. Thefollowed parameters were larvae length $(\mathrm{mm})$, larvae weight $(\mathrm{g})$, silk middle gland weight ( $\mathrm{g}$ ) and cocoon's weight (g), using methods described elsewhere (Dezmirean et al., 2018). Statistical interpretion was done using ANOVA 2 factor without replication for each trait, separately, using average values as starting point.

\section{Results and discussions}

The Global Centre of Excellence for Advanced Research in Sericulture and Promotion of Silk Production is a functional organisation in University of Agricultural Sciences and Veterinary Medicine Cluj Napoca with the main purpose of development of advanced research in sericulture. Being recognised by International Sericulture Commission, it owns an important role in Romanian sericulture and research. One of the main aims in research domain is to develop experimental models in order to provide high quality biological material for the researchers.

The research presented in this paper was developed in GCEARS-PSP in Cluj-Napoca during the autumn of 2018 and winter of 2019. Shinbo and Yanagan (1994) shows that at present, about $50 \%$ of the silkworms in their young instars are reared on artificial diets rather than on mulberry leaves, but the Romanian breeds and hybrids has not been tested under this system, and no publications regarding this theme are available.

Generally, the composition of an artificial diet for silkworms contain mulberry leaf powder, defatted soybean meal, cellulose powder, corn starch, citrate, salt mixture, sucrose, agar, ascorbic acid, vitamin B mixture, pytosterol, soybean oil and antiseptics (Horie et al., 1983; Asaoka et al., 1992); as we used a commercial product, the adding of bee pollen in $1 \%$ and $5 \%$ was done, in order to not deprive the silkworms from the necessary quantity of proteins. In the first three instars all silkworms were fed ad libitum with V1 receip (without bee pollen) and in the fourth and fifth instar the V2 


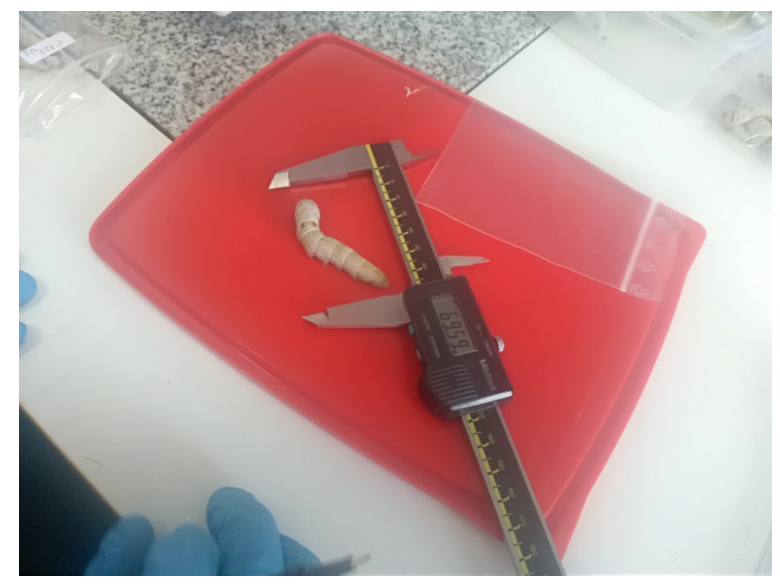

Figure 2. The measurement of larvae length (mm)

Table. 1. The main characteristics of silkworm that have been fed with different formulas of artificial diet

\begin{tabular}{ccccc}
\hline $\begin{array}{c}\text { Silkworms breed } \\
\text { /Recipe }\end{array}$ & $\begin{array}{c}\text { Larvae length } \\
(\mathrm{mm})\end{array}$ & $\begin{array}{c}\text { Larvae weight } \\
(\mathrm{g})\end{array}$ & $\begin{array}{c}\text { Silk middle } \\
\text { gland weight }(\mathrm{g})\end{array}$ & $\begin{array}{c}\text { Cocoon's weight } \\
(\mathrm{g})\end{array}$ \\
\hline $\mathrm{C} 122 / \mathrm{V} 1$ & $59.05 \pm 3.86$ & $3.06 \pm 0.37$ & $0.30 \pm 0.10$ & $1.08 \pm 0.30$ \\
\hline $\mathrm{C} 122 / \mathrm{V} 2$ & $58.33 \pm 3.58$ & $3.82 \pm 0.52$ & $0.36 \pm 0.04$ & $1.22 \pm 0.34$ \\
\hline $\mathrm{C} 122 / \mathrm{V} 3$ & $63.07 \pm 2.93$ & $3.22 \pm 0.42$ & $0.44 \pm 0.10$ & $1.26 \pm 0.17$ \\
\hline $\mathrm{JH} 3 / \mathrm{V} 1$ & $65.57 \pm 4.05$ & $3.70 \pm 0.49$ & $0.27 \pm 0.11$ & $1.04 \pm 0.12$ \\
\hline $\mathrm{JH} 3 / \mathrm{V} 2$ & $69.37 \pm 2.23$ & $4.10 \pm 0.38$ & $0.42 \pm 0.08$ & $1.06 \pm 0.20$ \\
\hline $\mathrm{JH} 3 / \mathrm{V} 3$ & $63.05 \pm 3.93$ & $3.73 \pm 0.36$ & $0.38 \pm 0.15$ & $1.23 \pm 0.34$ \\
\hline $\mathrm{A033} / \mathrm{V} 1$ & $57.49 \pm 2.64$ & $3.06 \pm 0.39$ & $0.36 \pm 0.07$ & $1.19 \pm 0.22$ \\
\hline $\mathrm{A} 033 / \mathrm{V} 2$ & $62.60 \pm 4.71$ & $3.82 \pm 0.52$ & $0.51 \pm 0.36$ & $1.20 \pm 0.27$ \\
\hline $\mathrm{A033} / \mathrm{V} 3$ & $64.12 \pm 2.42$ & $3.87 \pm 0.25$ & $0.44 \pm 0.10$ & $1.50 \pm 0.23$ \\
\hline $\mathrm{B} 1 / \mathrm{V} 1$ & $64.44 \pm 5.86$ & $3.76 \pm 0.39$ & $0.24 \pm 0.09$ & $0.99 \pm 0.16$ \\
\hline $\mathrm{B} 1 / \mathrm{V} 2$ & $67.68 \pm 2.29$ & $3.88 \pm 0.33$ & $0.25 \pm 0.09$ & $1.03 \pm 0.09$ \\
\hline $\mathrm{B} 1 / \mathrm{V} 3$ & $64.78 \pm 2.23$ & $3.89 \pm 0.17$ & $0.26 \pm 0.08$ & $1.09 \pm 0.31$ \\
\hline
\end{tabular}

(containing $1 \%$ bee pollen) and V3 (containing 5\% bee pollen) receipe were introduce for each breed. The experimental groups were formed at the beginning of the fourth instar and the silkworms were kept in plastic boxes (Figure 1B).

The larvae length $(\mathrm{cm})$ (Figure 2), the larvae weight (g) and the middle part of silk gland (g) were measured in the fifth day of the fifth instar and the results are presented in Table 1.

The results presented in this paper represent the average of two experimental repetitions (2018 and 2019); every biological parameter was measured for 20 larvae or cocoons randomly choose from the same experimental group (200 larvae/ box). Regarding the larvae length ( $\mathrm{mm}$ ) the JH3 breed registered the best evolution (69.37 $\mathrm{mm}$ ) in the experimental group fed with $1 \%$ bee pollen added in the artificial diet. The same experimental group (JH3/V2) registered the best value of larvae weight $(4.1 \mathrm{~g})$, as well. These two parameters are positively correlates, as showed by other authors before (Benţea et al., 2004; Benţea, 2006) and for our experimental groups the correlation between larvae's length and weigh was 0.64 ; the correlation between the weight of middle silk gland and cocoon's weight of the same breed was 0.68 .

Different authors (Kędzia and HołdernaKędzia, 2005; Kędzia and Hołderna-Kędzia, 2012; Almeida-Muradian et al., 2005) states that bee pollen contains $22,7 \%$ of protein, including $10,4 \%$ of essential amino acids such as methionine, lysine, 
Table 2. Differences between the traditional food system and different formulas of artificial diet

\begin{tabular}{|c|c|c|c|c|c|}
\hline \multirow{2}{*}{$\begin{array}{l}\text { Biological } \\
\text { parameter }\end{array}$} & \multirow{2}{*}{$\begin{array}{l}\text { Silkworms } \\
\text { breed* }\end{array}$} & \multirow{2}{*}{$\begin{array}{c}\text { Traditional food } \\
\text { (mulberry leaves, } a d \\
\text { libitum)** }\end{array}$} & \multicolumn{3}{|c|}{ Differences between } \\
\hline & & & $\begin{array}{l}\text { V1 and traditional } \\
\text { food }\end{array}$ & $\begin{array}{l}\text { V3 and traditional } \\
\text { food }\end{array}$ & $\begin{array}{c}\mathrm{V} 3 \\
\text { and V1 }\end{array}$ \\
\hline \multirow{3}{*}{$\begin{array}{l}\text { Larvae length } \\
\text { (mm) }\end{array}$} & $\mathrm{A033}$ & 67.58 & -10.09 & -3.46 & 6.63 \\
\hline & C122 & 71.85 & -12.8 & -8.78 & 4.02 \\
\hline & B1 & 69.85 & -5.41 & -5.07 & 0.34 \\
\hline \multirow{3}{*}{$\begin{array}{c}\text { Cocoon's weight } \\
\text { (g) }\end{array}$} & A033 & 1.225 & -0.035 & 0.275 & 0.31 \\
\hline & C122 & 1.457 & -0.377 & -0.197 & 0.18 \\
\hline & B1 & 1.521 & -0.531 & -0.431 & 0.1 \\
\hline
\end{tabular}

Note: * no data available about JH3 breed traditional nutrition; for this reason was excluded from this table; ** Results according to Dezmirean et al., 2018.

Table 3. Variance of average performances of studied parameters using ANOVA test

\begin{tabular}{|c|c|c|c|c|c|c|c|c|c|c|c|c|}
\hline \multicolumn{7}{|c|}{ Larvae Length (mm) } & \multicolumn{6}{|c|}{ Larvae Weight (g) } \\
\hline $\begin{array}{l}\text { Source of } \\
\text { Variation }\end{array}$ & SS & $\mathrm{df}$ & MS & $\mathrm{F}$ & P-value & F crit & SS & df & MS & $\mathrm{F}$ & P-value & F crit \\
\hline Breed & 78.71 & 3.00 & 26.24 & 3.41 & 0.09 & 4.76 & 0.48 & 3.00 & 0.16 & 2.98 & 0.12 & 4.76 \\
\hline Diet & 17.60 & 2.00 & 8.80 & 1.14 & 0.38 & 5.14 & 0.52 & 2.00 & 0.26 & 4.89 & 0.06 & 5.14 \\
\hline Error & 46.16 & 6.00 & 7.69 & & & & 0.32 & 6.00 & 0.05 & & & \\
\hline Total & 142.47 & 11.00 & & & & & 1.32 & 11.0 & & & & \\
\hline \multicolumn{7}{|c|}{ Middle Silk Gland weight (g) } & \multicolumn{6}{|c|}{ Cocoon Weight $(\mathrm{g})$} \\
\hline $\begin{array}{l}\text { Source of } \\
\text { Variation }\end{array}$ & SS & $\mathrm{df}$ & MS & $\mathrm{F}$ & P-value & F crit & SS & $\mathrm{df}$ & MS & $\mathrm{F}$ & P-value & F crit \\
\hline Breed & 0.05 & 3.00 & 0.02 & 9.09 & 0.01 & 4.76 & 0.11 & 3.00 & 0.04 & 8.78 & 0.01 & 4.76 \\
\hline Diet & 0.02 & 2.00 & 0.01 & 5.53 & 0.04 & 5.14 & 0.08 & 2.00 & 0.04 & 9.64 & 0.01 & 5.14 \\
\hline Error & 0.01 & 6.00 & 0.00 & & & & 0.03 & 6.00 & 0.00 & & & \\
\hline Total & 0.09 & 11.00 & & & & & 0.22 & 11.00 & & & & \\
\hline
\end{tabular}

threonine, histidine, leucine, isoleucine, valine, phenylalanine, and tryptophan. These protein elements are life essential and the organism cannot synthesize them by itself. The silkworms normally synthetize these ones from mulberry leaves, in order to produce the silk, but in the artificialdiet the quantity may not be enough. Moreover, in the bee pollen, there are significant amounts of nucleic acids, especially ribonucleic one.

Digestible carbohydrates occur in the pollen in the amount of $30,8 \%$ on average. Reducing sugars, mainly fructose and glucose are present in this product in about 25,7\% (Roulston and Cane, 2000). As Table 1 show, the bee pollen added in artificial diet has a positive effect on almost all parameters (with the exception of larvae length and of (122 breed).
The silk gland weight is influenced by the bee pollen in all breeds (Table 3 ), but differences of $0.03 \mathrm{~g}$ (for B1 breed), $0.31 \mathrm{~g}$ (for A033 breed), $0.03 \mathrm{~g}$ (for JH3 breed) and $0.14 \mathrm{~g}$ (for $\mathrm{C} 122$ breed) cannot be considered representative, and the other researches will be done using bigger concentration of bee pollen in artificial diet. The fresh cocoon's weight is the parameter that responds positively at the presence of bee pollen in diet (Table 3). Differences of $0.1 \mathrm{~g}, 0.31 \mathrm{~g}$, $0.19 \mathrm{~g}$ and $0.18 \mathrm{~g}$ between $5 \%$ bee pollen (V3) and control group (V1) were registered for B1, A033, JH3 and C122 breeds. Some of the breeds taken in this experiment were studied before using the traditional food of the silkworms (Dezmirean et al., 2018) and the results are presented in Table 2. 
The results obtained for larvae length in $\mathrm{AO33}$ breed show that the fresh mulberry leaves gives better results than the artificial diet (a difference of $10.09 \mathrm{~mm}$ was registered), and this one decreases at $3.46 \mathrm{~mm}$ when $5 \%$ of bee pollen is added to artificial diet. Similar results are presented for the same character at $\mathrm{C} 122$ breed $(12.8 \mathrm{~mm}$ and 8.78 $\mathrm{mm}$ ), demonstrating once again the influence of bee pollen importance in artificial diet.

Comparing the cocoons weight $(\mathrm{g})$ for the same breeds (A033 and C122) we can conclude that differences between traditional food and artificial diet are not high, 0.035 and $0.377 \mathrm{~g}$, respectively and $5 \%$ bee pollen in the receipe improves cocoon's weight with $0.275 \mathrm{~g}$ in $\mathrm{AO} 3$.

As showed by ANOVA test (Table 3 ), the middle silk gland and cocoons weight are influenced by artificial diet ( $\mathrm{F}>$ Fcrit ).

All this comparative data shows that the artificial diet is a valuable food system for silkworms, in order to have biological material for laboratory research all over the year, but in-depth studies have to be conducted to demonstrate the effect of artificial diet on silk quality.

\section{Conclusion}

This study represents the first step in testing the effect of artificial diet on silkworms in Romania. The results show that the silkworms have good adaptability at the presented conditions and the artificial diet can function with good results, in order to provide biological material for researches. The concentration of $1 \%$ bee pollen in artificial diet brings an added value to all tested biological parameters, but not in all cases the differences are representatives. The concentration of 5\% doesn't give significant differences compared with de $1 \%$ bee pollen concentration.

Further studies will be carried on GCEARSPSP, in order to study the biological effect of supplying the artificial diet of silkworms.

Acknowledgments. This research work was carried out with the support of University of Agricultural Science and Veterinary Medicine ClujNapoca, Romania.

\section{References}

1. Almeida-Muradian LB, Pamplona LC, Coimbra S, Barth OM (2005). Chemical composition and botanical evaluation of dried bee pollen pellets, Journal of Food Composition and Analysis, 18(1): 105-111.

2. Asaoka K, Mano Y (1992). Breeding of polyphagous silkworm by early selection for feeding ability on LP-1 artificial diet. Journal of Sericulture Sciences Jpn, 61: 1-5 [in Japanese with English summary].

3. Babu M., Swamy MT, Rao PK, Rao MS (1992). Effect of ascorbic acid-enriched mulberry leaves on rearing of Bombyx mori L. Indian Journal of Sericulture, 31: 111-114.

4. Benţea M, Mărghitaş LAl, Dezmirean D, Matei A, Vlaic B (2004). Research upon some morphological traits in Bombyx mori L., Bulletin USAMV-CN, 60: 268-273.

5. Bențea M. (2006). Caracterizarea unor hibrizi de viermi de mătase (Bombyx mori L.) crescuţi în zona Transilvaniei. Teză de doctorat. USAMV CN.

6. Bhattacharyya P, Jha S, Mandal P, Ghosh A (2016). Artificial Diet based Silkworm Rearing System - A Review. International Journal of Pure \& Applied Biosience, 4(6): 114-122.

7. Capellozza L, Capellozza S, Saviane A, Sbrenna G (2005). Artificial diet rearing system for the silkworm Bombyx mori (Lepidoptera: Bombycidae): effect of vitamin C depravation on larval growth and cocoon production. Applied Entomology and Zoology, 40: 405-412.

8. Chamudeswari P, Radhakrishnaiah K (1994). Effector Zinc and Nickel on the silkworm Bombyx mori L. Sericologia, 34: 327-332.

9. Das S, Medda A (1988). Effect of cyanocobalamine on protein and nucleic acid contents of ovary of silkworm, Bombyx mori L. during larval, pupal and adult stages of development. Insect Sci Appl., 9: 641-646.

10. Dezmirean D, Mărghitaş LA, Bobiş O, Urcan AC, Dezmirean H, Paşca C, Moose AR (2018). Multidirectional activities for gene pool conservation in GCEARS-PSP. Bulletin UASVM Animal Science and Biotechnologies, 75(1): 5-10.

11. El-Hattab, Samia M (2002). Evaluation of various kinds of dietary proteins in semiartificial diets on the mulberry silkworm Bombyx mori. Journal of Insects Physiology, 29: 187-199.

12. El-Sayed, Nagda AA (1999). Evaluation of six mixtures of food additives on some biophysiological and reproductively parameters of the mulberry silkworm Bombyx mori L. Monofia. Journal of Agricultural Research, 24: 1971-1986.

13. Etebari K, Ebadi R, Fazilati M (2002). Effect of ascorbic acid and multi vitamin on biological and economical characteristics of silkworm Bombyx mori L., Proceeding of $15^{\text {th }}$ Iranian plant protection Congress. Kermansha, 160.

14. Horie Y, Watanabe K, Shinohara (1971). Effect of dietary composition on growth, silk glands and components in haemolymph of the silkworm. Acta Sericologia Japan, 78: 44-50.

15. Horie Y, Watanabe K (1983). Design of the composition of the artificial diets for the silkworm Bombyx mori, by linear programming method: application of the ingredients of 
feeds for domesticated animals and fowls. Bull. Seric. Exp. Stn, 29: 259-283.

16. 16. Horie Y, Watanabe K (1983). Effect of various levels of dietary protein and supplementation with limiting amino acids on growth, haemolymph components and uricacid excretion in silkworm, Bombyx mori. Journal of Insects Physiology, 29: 187-199.

17. Islam R, Ali AO, Paul, DK, Sultana S, Banu NA, Islam R. (2004). Effect of salt, nickel chloride supplementation on growth of silkworm Bombyx mori L. (Lepidoptera: Bombycidae). Journal of Biological Sciences, 4: 170-172.

18. Kanafi R, Ebadi R, Mirhosseini SZ, Seidavi AR, Zolfaghari M, Etebari K. (2007). A review on nutritive effect of mulberry leaves enrichment with vitamins on economic traits and biological parameters of silkworm Bombyx mori $L$, Information Systems Journal, 4: 86-91.

19. Kędzia B, Hołderna-Kędzia E (2012). New studies on biological properties of pollen, Postępy Fitoterapii, 1: 48-54.

20. Kędzia B, Hołderna-Kędzia E (2005). Biological properties and therapeutic action of bee pollen, Postępy Fitoterapii, 3-4: 103-108.

21. Liaw GJ (1990). Application of artificial diet to the rearing of domestic silkworm, Bombyx mori L.. Chinese Journal of Entomology, Special Publ., 5: 37-45.

22. Roulston TH, Cane JH (2000). Pollen nutritional content and digestibility for animals, Plant Systematics and Evolution, 222 (1-4): 187-209.
23. Shimbo H, Yanagaw Hiro-aki (1994). Low-cost artificial diets for polyphagous silkworms. Japan Agricultural Research Quarterly, 28: 262-267.

24. Vlaic BA, Mărghitaş LAl, Dezmirean D, Vlaic A (2006a), Research concerning the influence of the treatment, harvesting moment and level of which mulberry leaf was harvested on the weight of the silkworm larvae at $\mathrm{V}^{\text {th }}$ age, Bulletin USAMV CN, 62:164-169.

25. Vlaic BA, Mărghitaş LAl, Matei A, Dezmirean D, Vlaic A, (2006b), Research concerning the influence of the treatment, harvesting moment and level of which mulberry leaf was harvested on the technological indices of the cocoon, Bulletin USAMV CN, 62: 170-175.

26. Vlaic BA, Mărghitaş LAl, Matei A, Dezmirean D, Vlaic A (2008). Research concerning the influence of the treatment, harvesting moment and level of which mulberry leaf was harvested on the weight of the serigene gland, The Proceedings of the First International Conference "Sericulture - from tradition to modern biotechnology" Cluj-Napoca 17-18 April, ISBN 978-973-744-109-6, pp. 162-167.

27. Yanagawa H, Watanabe K, Suzuki K (1991). Development of a low-cost artificial diet - Development of an artificial diet by applying a linear programming method for polyphagous strains of the silkworm, Bombyx mori, Bulletin NISES, 3: 57-75 